\title{
FOOD PRODUCTION SYSTEMS, POLICIES AND RURAL PLANNING: CONTRIBUTIONS TO SUSTAINABILITY AND ENVIRONMENTAL IMPACT
}

\author{
WAYNE CALDWELL, REGAN ZINK, SARA EPP \& ELISE GESCHIERE \\ School of Environmental Design and Rural Development, University of Guelph, Canada
}

\begin{abstract}
A large portion of the most agriculturally-viable land in Canada is located in the province of Ontario. Within Ontario, municipal governments are the mechanism by which provincial land-use policy is implemented, and virtually all agricultural production happens within the boundaries of an upper-tier municipal government. This means that municipal governments are the most local level of government responsible for making decisions and implementing programs and policies related to the agriculture and agri-food sector. However, little is known about the structure, knowledge base, and capacity of municipal governments to respond to agricultural and agri-food priorities and issues. This paper reveals that the capacity of county planning departments is varied and presents a case for further research on this topic. The agricultural and agri-food sector is in a position where it both contributes and is extremely vulnerable to climate change; expertise is needed to manage both the risks and opportunities that rural communities face. It is imperative that governments and decision-makers who affect the agriculture and agri-food industry have capacity and knowledge to support the sector and respond to critical issues as they arise. The decisions of elected officials, the resources that municipalities have, and the expertise of staff are all key elements that affect implementation of provincial priorities and the consideration given to agriculture when creating policies, programs, and initiatives.

Keywords: municipal capacity, county/regional planning, agricultural planning, rural community development, climate change, Ontario.
\end{abstract}

\section{INTRODUCTION}

The Food and Agriculture Organization of the United Nations (FAO) defines sustainable food systems as ".... food system that delivers food security and nutrition for all in such a way that the economic, social and environmental bases to generate food security and nutrition for future generations are not compromised" [1]. Food and its long-term availability is critical to human health and survival. However, sustainable food systems are important for a number of other reasons including economic growth, environmental management, and social and cultural benefits.

In Canada, the agriculture and agri-food industry generates $\$ 110$ billion annually and employs over 2.3 million Canadians [2]. Canada is the fifth largest agricultural exporter in the world and as a result, Canadian agriculture plays an important role in feeding the Canadian population as well as communities around the globe [2]. It is imperative that governments and decision makers who affect the industry have capacity and knowledge to support the sector and respond to critical issues as they arise.

This paper considers the importance of County and Regional level planning in the Canadian province of Ontario as a means to address sustainable food production. County and Regional governments play a key role in planning for sustainable agriculture including local food systems, farmland preservation, and environmental stewardship. Case study analysis is used to identify key lessons that can be applied in Canada and other countries. 


\section{AGRICULTURE AND PLANNING IN ONTARIO}

Agriculture is delineated by Canada's Constitution Act as both a federal and provincial responsibility. Additional legislation, such as the Planning Act, Provincial Policy Statement, Greenbelt Plan, and Growth Plan for the Greater Golden Horseshoe transfer some of the decision-making power from the Federal and Provincial level to municipal governments with varying levels of autonomy [3]. Specific to agriculture, documents such as the Minimum Distance Separation formula, Ontario Ministry of Agriculture Food and Rural Affairs (OMAFRA) Guidelines on Permitted Use, and Agricultural Systems Planning provide guidance to municipalities who are expected to create policies and programs that reflect both provincial direction and local needs.

Municipal governments are the most local level of government responsible for making decisions and implementing programs and policies related to the agriculture and agri-food sector. Understanding municipal governments' functions and capacity will help protect and enhance local and global food systems and shift towards a more sustainable food system in Canada.

In Ontario, where a large portion of the most agriculturally-viable land in Canada can be found, there is significant variability in the structure of municipal government [4]. In the majority of rural areas there is both an upper-tier municipal government (county or region), and a lower-tier municipal government (typically, referred to as a town, township, city, or municipality). Upper-tier municipalities can be understood as the managers of a large geographic area; they ensure consistency, implement federal and provincial policy, and coordinate regional influence. They are responsible for implementing land-use policies (including the protection of prime agricultural lands), coordinating environmental stewardship efforts, and promoting local food systems. Whyte [5] identifies several factors impacting food systems in Ontario, including population growth, the loss of farmland, declining soil health, and water quality. These are similar to the challenges discussed in the publication titled Canada's Action Plan for Food Security which identified farmland loss, climate change, globalization, and imported foods as key threats to Canadian food security [6].

Historically, agriculture and food systems were not explicitly viewed as part of the planning portfolio [7]-[9]. Connell et al. [3] discuss how counterintuitive this seems as agriculture and agri-food industries are dependent on both the spatial availability and physical health of the land. It was not until the 1970s that farmland conservation became a major discussion and provincial legislation mandating its protection at the municipal level was put in place [10]. Today, county and regional governments, in particular planning departments, play a critical role in sustainable food production and agriculture and agri-food industries [3], [11].

The effectiveness and success of municipalities is largely dependent on the capacity and knowledge of both elected officials and staff. However, there is little research regarding the structure, knowledge base, and capacity of upper-tier governments to respond to agricultural and agri-food priorities and issues.

The remainder of this paper provides an overview of the topic and investigates the role of municipal government and planning in agricultural and agri-food systems in two case-study locations in Ontario. Three themes have been identified and will be explored:

1. The importance of land-use planning tools to protect and ensure that a land base is available for agricultural production.

2. Key actions that can be taken by municipal governments to develop a local food sector. 
3. Strategies to encourage more sustainable agricultural production with accompanying environmental enhancements.

\section{LITERATURE REVIEW: CONNECTING ACADEMIA TO PRACTICE}

While the issue of agricultural land preservation in Canada has been a topic of discussion for well over forty years [12], there is limited literature that addresses municipal capacity related to agriculture and agri-food systems from a food systems perspective in Ontario.

Davidson [13] completed the most recent study looking at the capacity of 13 upper-tier planning departments in Ontario. He provides historical context to the varied efforts of municipalities and identifies two general issues impacting upper-tier planning. First, he suggests that over-optimistic expectations had been established (i.e. mandates had expanded but resources had not) and second, he notes inter-municipal jurisdictional challenges (particularly between upper and lower-tier municipalities) [13]. Davidson also documents the capacity of municipalities in terms of the presence or absence of planning departments at the upper-tier and their related budgets - pointing to the fundamental relationship between capacity and the ability to deliver on key and evolving planning mandates.

Some of the trends Davidson [13] identifies are as relevant today as they were in 1988 when the study was published. Within Ontario, the capacity of municipal planning departments to address current agricultural and agri-food issues and implement related policy is intermittent and varied at best. For example, Halton Region has significant resources but has struggled with issues related to agriculture and natural heritage designations [14]. Similarly, Perth County, which has some of the most pristine and valuable farmland in the country, wrestled with issues such as surplus farm lot severance policies in 2015 [15]. Beyond these examples, there are clear differences in the staff capacity of planning departments across the province of Ontario. Table 1 provides examples of the wide range of staff resources available at the county level and shows that a county could have as few as 1 and as many as 14 planners on staff. While this disparity could be explained by the population and geographic size of the county, it should be remembered that planning is critical for both the management of communities and land.

Table 1: Capacity of a sample of Ontario counties [16], [17].

\begin{tabular}{|l|c|c|c|c|}
\hline County & $\begin{array}{c}\text { Planning staff } \\
\text { (full-time) }\end{array}$ & Area $\left(\mathrm{km}^{2}\right)$ & Population & $\begin{array}{c}\text { Total value of } \\
\text { agricultural sales } \\
\text { \$'000 (CAD) }\end{array}$ \\
\hline Dufferin County & $<2$ & $1,486.44$ & 61,735 & 157,496 \\
\hline Elgin County & $<1$ & $1,881.03$ & 88,978 & 432,562 \\
\hline Huron County & 9 & $3,399.27$ & 59,297 & $1,234,394$ \\
\hline Oxford County & 8 & $2,039.61$ & 110,862 & 910,779 \\
\hline Wellington County & 14 & $2,657.00$ & 90,932 & 943,243 \\
\hline
\end{tabular}

Davidson [13] also speaks to the evolving relationship between and capacity of upper and lower-tier municipalities. This continues to be of particular interest within the area around Toronto commonly referred to as the Greater Golden Horseshoe. In this area, the rural landscape is contested because of its high soil quality and ideal geographic location. Caldwell and Procter [18], in their report titled Possibility Grows Here, identify the differing capacity of regional planning departments, noting that some regions had developed important staff capacity to deal with agricultural issues while others had not. Where this capacity existed, 
there was a notable difference in the responsiveness by planning departments to the needs of agriculture [18]. Epp [19] provides insight into the importance of the municipal relationship to the agricultural community. Her work looking at Agricultural Advisory Committees in the Golden Horseshoe identifies the potential for innovative planning practices and systems in an area where agriculture must contend with a rapidly growing urban community.

Across the province, municipalities are pursuing a wide spectrum of initiatives related to the agricultural sector. These initiatives include agricultural strategies (e.g. Middlesex County), climate change strategies (e.g. Grey County), water quality programs (e.g. Wellington County), and the creation of policies that provide enhanced support and protection for agriculture and agri-food beyond the requirements set out by the provincial government (e.g. Waterloo Region). Further to this, some municipalities have Agricultural Advisory Committees and dedicate resources to building positive relationships with the farm community (e.g. Huron County), while others may not.

Many of the aforementioned activities, policies, and initiatives are not mandated by upper levels of government and as such, their creation is largely a result of elected officials and staff initiative, capacity, and knowledge.

There are limited studies examining the challenges rural Ontario municipalities face when dealing with complex and multifaceted issues such as climate change. Research in this field has identified rural economies (e.g. reduced agricultural production owing to delayed seasonal changes), the health and safety of residents, and community infrastructure as key areas of risk in rural communities (Bi and Parton [20], Dasgupta et al. [21], Lal et al. [22]). Waldick et al. [23] identify constraints related to fragmentation and capacity as some of the largest challenges for climate change adaptation in agricultural regions in Eastern Ontario.

A scan of municipal websites provides information on a variety of initiatives. For example, the Federation of Canadian Municipalities recently secured $\$ 75$ million in funding for their Municipalities for Climate Innovation Program. Some rural municipalities have taken advantage of this program and others have not. Grey County is an example of a municipality that is actively seeking strategies that can help evaluate the role of agriculture in addressing climate change. Likewise, Waterloo Region and Wellington and Huron Counties have taken a proactive response to water quality issues; combined, their water quality programs have funded thousands of projects. These examples raise interesting questions related to why these municipalities are embracing agriculture to this extent, while others do not.

These observations, based in Ontario, are reflected in the results of research conducted in other geographic areas. In the United States, Daniels [24], Daniels and Payne-Riley [25], and Dillemuth [26] note the role of public support, political will, focus on relevant issues, culture, and staff and financial resources in determining capacity of planning departments to explore options, build public support, and engage local politicians. Similarly, Larson et al. [27] evaluate municipal capacity to respond to environmental change in three different regions in New York State and look at factors including essential resources (economic and human), social networks and collaboration (the public, NGOs, and other industries), and political legitimacy (including public trust in the government). In the Australian context, Budge and Butt [28], note the importance of planners in raising issues related to farmland preservation and the potential of a coalition between planners and farmers to create greater profile for the industry and the importance of land. Caldwell and Lang [9] identify land tenure, climate change, land use change (and associated conflicts), farmland preservation, the development of local food systems, and sustainable land and water management as key issues facing planners across the Commonwealth. 


\section{CASE STUDIES: HURON AND WELLINGTON COUNTY}

Both Huron and Wellington counties are located in southern Ontario and have strong agricultural sectors. Huron is a predominantly rural county (population density of 17.4 people per $\mathrm{km}^{2}$ ) and faces unique challenges related to its location along the shore of Lake Huron. Wellington has a population density of 34.2 people per $\mathrm{km}^{2}$ and faces a slightly different set of issues, mostly associated with its proximity to Toronto and resulting urban development pressures [29]. Table 1 provides a brief summary of both counties.

Owen [30] identifies the importance of both document analysis and interviews in understanding policies and the underlying values of organizations. Staff at both counties were interviewed in the preparation of this article.

\subsection{Farmland preservation}

As mentioned previously, the protection of agricultural lands in Ontario was first legislated in the 1970s and to this day is primarily policy and process-driven [10], [31]. Both Huron and Wellington County Official Plans contain policies that pertain to prime agricultural land (soil classes 1, 2, and 3) [4], [32], [33]. Staff from both counties discussed the important role that policy plays in providing consistency and ensuring farmland is not redesignated for another, less compatible use. Further to this, Caldwell [31] and Caldwell et al. [34] identify that it is not only the physical loss of farmland that threatens agriculture; it is also the disruption of continuous agricultural lands for a less compatible use that may cause conflict and as a result reduced agricultural productivity in the future (e.g. farm lots that are not economically viable, or issues with odour or noise).

The Huron County Official Plan contains policies to allow for agricultural industrial uses in specific scenarios where the agricultural and agri-food sector may benefit from a use that is more industrial than typically allowed [32]. An example of this type of development is a canola seed cleaning plant. Huron staff explained that allowing for this type of use in an agricultural setting not only generates economic growth but also reduces transportation time and cost for farmers who grow canola.

Staff at both counties also discussed issues related to consistency. While Huron staff felt council was well positioned to make consistent decisions in favour of protecting farmland, they also discussed the role of the planning department in advising when a decision had the potential to be precedent-setting in a way that would hinder agricultural viability in the county. In contrast, Wellington staff felt that consistency was important to council but that the recent decline of farmers on council has resulted in missed perspectives and knowledge.

\subsection{Local food systems}

Looking at local food sectors, there was less consensus about the role of planning and council. Connell et al. [3] argue that farmland protection is a good starting point to ensuring sustainable food production, however supplementary management activities are required to build strong rural communities. Caldwell and Lang [9] point out that less than $3 \%$ of Canadians are farmers and as a result there is a clear disconnect between consumers and agricultural producers and processors. Raja et al. [35] suggest that land use planning should play a role in promoting and strengthening local agri-food networks.

In both counties, staff discussed the need to celebrate agriculture and publish statistics about the economic contributions of the agriculture and agri-food sectors. Wellington County, for example, organizes two annual rural romps celebrating the agriculture sector and providing the opportunity for residents to get "up close to your food" [36]. Both counties 
have also taken advantage of "eat local" movements through programs such as Taste of Huron and Taste Real and provide support for local farmers markets. While neither county specifically discussed the associated benefits of these programs, Caldwell et al. [12] suggest that building consumer-producer relationships at the local level may also help to reduce conflict in rural areas. It should be noted that none of these initiatives are mandated or facilitated through provincial or federal levels of government and their conception and resource support is entirely driven by the will of council, staff, and third-party partners.

\subsection{Environmental stewardship}

Similarly, environmental stewardship initiatives intended to help rural communities adapt to and mitigate climate change are not facilitated by upper levels of government. Huron staff discussed the importance of balancing policy, education, and stewardship incentives to improve community reception of new initiatives. Both Huron and Wellington Counties have established water quality projects in association with local conservation authorities and have received incredible participation rates from their communities, largely due to the availability of funds. The Huron Clean Water Project began in 2004 and has completed over 2,900 projects [37]. The Wellington Rural Water Quality Program began in 1999 and has completed over 1,650 projects [38].

The agricultural and agri-food sector is in a position where it both contributes and is extremely vulnerable to climate change [12]. Improving water quality and agricultural practices is not only helpful in mitigating environmental impact, it also provides economic benefits associated with improved soil and water health [7]. Huron County talked about the role of county council and staff in being leaders by undertaking additional stewardship initiatives such as Huronview Farm which is leased out to the Huron Soil and Crop Improvement Association and acts as a testing site for new technologies and agricultural practices. Huron County also played a role in the creation of the Water Protection Steering Committee and the continuation of the Huron Stewardship Council (after Provincial funding was cut). A similar example of leadership in Wellington County is the Green Legacy program which was recognized by the UN Billion Tree Campaign for its role in mitigating climate change.

\section{CONCLUSION}

The role of municipal governments in agriculture is critically important not only to preserve farmland, but also to ensure long-term economic, social, and environmental sustainability. Beyond this, municipalities are the mechanism by which provincial land-use policy is implemented. The Planning Act, Provincial Policy Statement, Greenbelt Plan, and Growth Plan are all implemented through local planning. Additionally, issues related to severance policy, aggregate operations, and greenhouses/cannabis production are examples of matters that are important provincially, but are implemented through municipal action. The decisions of elected officials, the resources that municipalities have, and the expertise of staff are all key elements that affect implementation of provincial priorities and the consideration given to agriculture when creating policies, programs, and initiatives.

There has been little research conducted regarding the structure, knowledge base, and capacity of upper-tier governments to respond to agricultural and agri-food priorities and issues. This brief introduction to the topic is a base for future research and presents the following key lessons:

1. Ontario has been successful in protecting farmland. Both provincial and municipal commitment have been key in ensuring protective policies continue to be effective. 
However, some counties and regions have been more successful; further research is needed to determine the role of staff and elected officials in this variability.

2. Rural communities are unique and the issues they face are often complex and contextspecific. It is imperative that staff and elected officials be equipped to support and respond to agricultural and agri-food priorities and issues.

3. There is still much to learn about municipal capacity related to agriculture and agri-food initiatives. Understanding the structure, knowledge base, and capacity of upper-tier governments will be key to long-term agricultural planning in Ontario, particularly northern communities where climate change will introduce new agricultural capability.

\section{ACKNOWLEDGEMENTS}

We would like to thank the Greenbelt Foundation for supporting this project. Additionally, we would like to thank Huron and Wellington County staff for their input.

\section{REFERENCES}

[1] Food and Agricultural Organization of the United Nations (FAO), Sustainable food systems, concept and framework. www.fao.org/3/ca2079en/CA2079EN.pdf. Accessed on: 15 Feb. 2020.

[2] Agriculture and Agri-food Canada, We grow a lot more than you may think. www.agr.gc.ca/eng/about-our-department/publications/we-grow-a-lot-more-thanyou-may-think/?id=1251899760841. Accessed on: 15 Feb. 2020.

[3] Connell, D.J. et al., Food sovereignty and agricultural land use planning: The need to integrate public priorities across jurisdictions. Journal of Agriculture, Food Systems, and Community Development, 3(4), pp. 117-124, 2013.

[4] Environment Canada, Lands directorate. Canada land inventory report no. 10: Land capability for agriculture, preliminary report, Environment Canada: Ottawa.

[5] Whyte, B., Planning tools for improving food access: Lessons for Ontario's municipal planners. Major Research Paper, Ryerson University, 2011.

[6] Agriculture and Agri-Food Canada, Canada's action plan for food security, 1998. www.agr.gc.ca/misb/fsec-seca/pdf/action_e.pdf. Accessed on: 15 Feb. 2020.

[7] Caldwell, W., Collett, A., Ludlow, T., Sinclair, I. \& Whitehead, J., Planning and food security within the Commonwealth: Discussion paper, Commonwealth Association of Planners, 2011.

[8] American Planning Association, APA policy guide on community and regional food planning, 2007. www.planning.org/policy/guides/adopted/food.htm. Accessed on: 15 Feb. 2020.

[9] Caldwell, W. \& Lang, K., Perspectives on planning for agriculture and food security in the Commonwealth, Commonwealth Association of Planners, 2014.

[10] Caldwell, W., Hilts, S. \& Wilton, B., Farmland Preservation: Land for Future Generations, 2nd ed., University of Manitoba Press: Winnipeg, 2017.

[11] Buchan, R., Cloutier, D., Friendman, A. \& Ostry, A., Local food system planning: The problem, conceptual issues, and policy tools for local government planners. Canadian Journal of Urban Research, 24(1), pp. 1-23, 2015.

[12] Caldwell, W., Dodds-Weir, C. \& Eckert, A., Lot creation in Ontario's agricultural landscapes: Trends, impacts and policy implications, report 1: Literature review, School of Environmental Design and Rural Development, University of Guelph, 2012.

[13] Davidson, G., Assimilation and accommodation: County planning in transition. Presented at 1988 Annual General Meeting, Southwestern Ontario Division, Ontario Planners Institute, Owen Sound, Canada, 1988. 
[14] Heck, A., This policy has Halton farmers fuming, and the province and the region can't agree on what to do. The Independent and Free Press, 5 Sep. 2018. www.theifp.ca/ news-story/8881085-this-policy-has-halton-farmers-fuming-and-the-province-andthe-region-can-t-agree-on-what-to-do/. Accessed on: 15 Feb. 2020.

[15] Beitz, M., Surplus farm dwelling severances remain a divisive issue. The Mitchell Advocate, 29 Jun. 2015. www.mitchelladvocate.com/2015/06/29/surplus-farmdwelling-severances-remain-a-divisive-issue/wcm/c8c28679-feec-2e24-09b42ea57b2c89d6. Accessed on: 15 Feb. 2020.

[16] Statistics Canada, Census profile, 2016 census. www12.statcan.gc.ca/censusrecensement/2016/dp-pd/prof/index.cfm?Lang=E. Accessed on: 15 Feb. 2020.

[17] Ontario Ministry of Agriculture Food and Rural Affairs (OMAFRA), Census farms classified by economic class and total value of sales, by county, Ontario, 2016. www.omafra.gov.on.ca/english/stats/census/cty34_16.htm. Accessed on: 15 Feb. 2020.

[18] Caldwell, W. \& Procter, K., Possibility Grows Here, Friends of the Greenbelt Foundation: Toronto, 2013.

[19] Epp, S., Agricultural Advisory Committees: Recognizing the Value of Agriculture in the Golden Horseshoe, Friends of the Greenbelt Foundation: Toronto, 2018.

[20] Bi, P. \& Parton, K.A., Effect of climate change on Australian rural and remote regions: What do we know and what do we need to know? Australian Journal of Rural Health, 16, pp. 2-4, 2008.

[21] Dasgupta, P. et al., Rural areas. Climate Change 2014: Impacts, Adaptation, and Vulnerability. Part A: Global and Sectoral Aspects. Contribution of Working Group II to the Fifth Assessment Report of the Intergovernmental Panel on Climate Change eds C.B. Field et al., Cambridge University Press: Cambridge and New York, pp. 613657, 2014.

[22] Lal, P., Alavalapati, J.R.R. \& Mercer, E.D., Socio-economic impacts of climate change on rural United States. Mitigation and Adaptation Strategies for Global Change, 16, pp. 819-844, 2011.

[23] Waldick, R., Bizikova, L., White, D. \& Lindsay, K., An integrated decision-support process for adaptation planning: climate change as impetus for scenario planning in an agricultural region of Canada. Regional Environmental Change, 17(1), pp. 187-200, 2017.

[24] Daniels, T., The Napa County agricultural preserve: Fifty years as a foundation of America's premier wine region. Journal of Planning History, 18(2), pp. 102-115, 2019.

[25] Daniels, T. \& Payne-Riley, L., Preserving large farming landscapes: The case of Lancaster County, Pennsylvania. Journal of Agriculture, Food Systems, and Community Development, 7(3), pp. 67-81, 2017.

[26] Dillemuth, A., Farmland protection: The role of local governments in protecting farmland as a vital local resource. Planning and Policy Briefs. Growing Food Connections, eds K. Hodgson \& S. Raja, 2016. http://growingfoodconnections.org/ wp-content/uploads/sites/3/2015/11/GFCPlanningPolicyBrief_FarmlandProtection 2017Sept1.pdf. Accessed on: 12 Nov. 2019.

[27] Larson, L.R., Lauber, T.B., Kay, D.L. \& Cutts, B.B., Local government capacity to respond to environmental change: Insights from towns in New York state. Environmental Management, 60(1), pp. 118-135, 2017. 
[28] Budge, T. \& Butt, A., Farmland preservation in Australia: Emerging issues and fragmented responses. Farmland Preservation, Land for Future Generations, 2nd ed., eds W. Caldwell, S. Hilts \& B. Wilton, University of Manitoba Press: Winnipeg, 2017.

[29] Epp, S., Drake, E. \& Caldwell, W., Land use planning and agriculture: Measuring prime agricultural land conversion in Wellington County, Ontario. Studies by Undergraduate Researchers at Guelph, 9(2), 2017.

[30] Owen, G., Qualitative methods in higher education policy analysis: Using interviews and document analysis. The Qualitative Report, 19(26), pp. 1-19, 2013.

[31] Caldwell, W.J., Rural planning and agricultural land preservation: The experience of Huron County, Ontario. The Great Lakes Geographer, 2(2), pp. 21-34, 1995.

[32] Huron County, Official Plan, 24 Sep. 2015. www.huroncounty.ca/wp-content/ uploads/2013/08/Huron_Official-Plan_2015.pdf. Accessed on: 15 Feb. 2020.

[33] County of Wellington, Official Plan, 15 Aug. 2019. www.wellington.ca/en/residentservices/resources/Planning/Official-Plan/Wellington-County-Official-Plan--August-15-2019.pdf. Accessed on: 15 Feb. 2020.

[34] Caldwell, W., Churchyard, A., Dodds-Weir, C., Eckert, A. \& Procter, K., Lot creation in Ontario's agricultural landscapes: Trends, impacts and policy implications, Report 3: Impacts and analysis, School of Environmental Design and Rural Development, University of Guelph, 2011.

[35] Raja, S., Born, B. \& Kozlowski Russell, J., A planner's guide to community and regional food planning: Transforming food environments, building healthy communities, Planning Advisory Service Report Number 554, American Planning Association: Chicago, IL, 2008.

[36] Wellington County, 14th annual taste real fall rural romp. www.wellington.ca/en/ business/tr-fallruralromp.aspx. Accessed on: 15 Feb. 2020.

[37] Huron County, Clean water project brochure, 2018. www.huroncounty.ca/wp-content/ uploads/2018/05/Huron_Clean_Water_Project_Brochure_2018_Web-3.pdf. Accessed on: 15 Feb. 2020.

[38] Wellington County, Rural water quality. www.wellington.ca/en/resident-services/ ruralwaterquality.aspx. Accessed on: 15 Feb. 2020. 